\section{Estimation of biomass, carbon stocks and leaf litter decompo- sition rate in teak Tectona grandis Linn plantations in city forest of Hasanuddin University, Makassar}

\author{
Slamet Santosa, ${ }^{1}$ Muhamad Ruslan \\ Umar, ${ }^{1}$ Dody Priosambodo, ${ }^{1}$ \\ Rizki Amalia P. Santosa ${ }^{2,3}$ \\ ${ }^{1}$ Biology Department, Faculty of \\ Mathematics and Natural Sciences, \\ Hasanuddin University, Makassar; \\ ${ }^{2}$ Central Statistical Agency of South \\ Sulawesi; ${ }^{3}$ Post Graduade Program of \\ Indonesia University, Indonesia
}

\begin{abstract}
Teak Tectona grandis Linn is still used as the main product in the form of wood, while other products, especially environmental services have not received much attention. This study analyzed biomass, carbon stocks and decomposition rate of leaf litter in teak plantations in city forest of Hasanuddin University, Makassar. The individual biomass of teak plants is calculated using the allometric equation $\mathrm{Y}=0.11 \mathrm{x} \rho \mathrm{x}$ $\mathrm{D}^{2.62}$. Carbon stocks were analyzed using a formulation $\mathrm{C}=0.47 \mathrm{xB}$. The leaf litter decomposition rate is expressed as the ratio of the remaining litter dry weight, with the formulation $\mathrm{X}=(\mathrm{A}-\mathrm{B}) / \mathrm{A}$. The number of teak plants in 5 sample plots were 239 trees with an average stem diameter of $20.6 \mathrm{~cm}$ and an average height of $9.02 \mathrm{~m}$. Total biomass in 5 sample plots was 51,712.61g. Carbon stocks in 5 sample plots was $24,304.92 \mathrm{~g}$. Decomposition rate average of leaf litter of $24.4 \mathrm{~g}$ during 60 days incubation. The existence of teak plantations is able to reduce $\mathrm{CO}_{2}$ in the atmosphere by as much as $89,199.06 \mathrm{~g} \mathrm{CO}_{2}$ and resulting in a decomposition rate of teak leaf litter $0.4 \mathrm{~g}$ per day.
\end{abstract}

\section{Introduction}

The Makassar campus of Hasanuddin University has an area of 220 ha planted with various types of trees to form the city forest. The presence of various trees causes the campus environment to be shady and cool. One type of tree planted is teak Tectona grandis Linn, whose wood is of high economic value and export commodities. ${ }^{1}$ The use of forest resources has tended to focus on the main products in the form of wood, while other products, especially environmental services, have not received much attention. Therefore, it is necessary to make an effort to manage forests that provide benefits outside of wood. One of them is to estimate the potential of stored carbon which is an environmental service in absorbing $\mathrm{CO}_{2}$ and storing it in the form of carbon so as to reduce the rate of global warming.

The forests have the potential to reduce $\mathrm{CO}_{2}$ in the atmosphere through storage in biomass as carbon stocks. The ability of trees to absorb and store carbon can be known from tree biomass. Tree biomass can be estimated using an allometric equation whose parameters are stem diameter. The large diameter of the stem causes the greater biomass and carbon stored, otherwise, the smaller the diameter, the smaller the biomass and carbon stored in it. ${ }^{3}$ Biomass is a living organic material that is above the soil surface and below the surface of the soil. Above ground biomass includes trees and under storey, which consists of stems, branches, bark and leaves. Geometric biomass has a relationship that is parallel to the diameter of the trunk, the density of wood, and height.

Teak Tectona grandis Linn is unique, namely the phenomenon of deciduous leaf occurring in the dry season each year. The source of biomass produced through this phenomenon is a large potential as a source of nutrients in the soil. ${ }^{4}$ Decomposition of organic matter is an important ecological process in a forest ecosystem. Through this decomposition process, litter that falls to the ground, along with the nutrient content in it is released into the soil and available to plants. ${ }^{5}$ Decomposition is an important process in terrestrial ecosystems. Decomposition of leaf litter contributes most of the nutrients to the forest floor, only a small fraction of the leaves are consumed directly by herbivorous animals. ${ }^{6}$ The rate of litter decomposition is strongly influenced by the content of the litter. The speed of litter weathering will correlate with the amount of microbes in the soil. The development of microbes itself depends on the availability of oxygen, soil moisture, soil temperature and litter as well as the elements contained in litter. Litter that is easily decomposed, will store less carbon mass and will only briefly act as mulch for the soil, whereas litter that is decomposed for longer will help protect the soil from falling rain, but will provide less soil nutrients.

\section{Materials and Methods}

The study was conducted on the teak
Correspondence: Slamet Santosa, Biology Department, Faculty of Mathematics and Natural Sciences, Hasanuddin University, Tamalanrea KM.10, Makassar, Indonesia Tel:+6285242113320

E-mail: slametsantosa@unhas.ac.id

Key words: Tectona grandis, biomass, $\mathrm{CO}_{2}$ uptake, leaf litter, nutrient avalaibility

Contributions: The authors contributed equally.

Conflict of interest: The authors declare no potential conflict of interest

Funding: Research Center of Hasanuddin University

Received for publication: 16 March 2020 Revision received: 15 September 2020.

Accepted for publication: 15 September 2020.

This work is licensed under a Creative Commons Attribution-NonCommercial 4.0 International License (CC BY-NC 4.0).

CC Copyright: the Author(s), 2020

Licensee PAGEPress srl, Italy

International Journal of Plant Biology 2020; 11:8541 doi:10.4081/pb.2020.8541

Tectona grandis Linn and the soil where it grew in the city forest of the Makassar campus of Hasanuddin University. The research was conducted for 6 months from July to December 2019. The materials and research equipment were Teak Tectona grandis Linn, leaf litter of teak, clinometer, phi band, length meter, rope, machete, litter bag size of $10 \times 10 \mathrm{~cm}$ with mesh of $2 \mathrm{~mm}$, digital scales, oven, camera, tally sheet, and computer.

\section{Determination of location and mak- ing of sample plots}

Determination of the research location is done by using purposive sampling technique. Purposive sampling technique is used intentionally by considering sample plots made of teak Tectona grandis Linn. Data collection in the study area was carried out using sample plots measuring $20 \times 20 \mathrm{~m} .{ }^{7}$ All teak plants in the sample plots were measured in stem diameter and height without harvesting (non destructive) and recorded.

\section{Estimation of biomass}

The calculated biomass is the above ground biomass obtained by measuring the stem diameter and height of the tree. The biomass estimation method follows ${ }^{8}$, i.e. total biomass of teak per sample plot area was obtained by adding up individual plant biomass. The individual biomass of teak plants is calculated using the allometric 
equation $\mathrm{Y}=0.11 \mathrm{x} \rho \mathrm{xD} \mathrm{D}^{2.62}$, where: $\mathrm{Y}=$ biomass $(\mathrm{g}) ; \rho=$ wood specific gravity $\left(\mathrm{g} / \mathrm{cm}^{3}\right.$ ) (wood specific gravity of teak $\left.=0.705 \mathrm{~g} / \mathrm{cm}^{3}\right) ; \mathrm{D}=$ stem diameter $(\mathrm{cm})$.

\section{Estimation of carbon stocks}

The value of known biomass is used to estimate the carbon stock stored in teak plants because $47 \%$ of the biomass is composed of carbon. ${ }^{9}$ The results of the calculation of biomass can be changed in the form of carbon $(\mathrm{g})$ through the process of multiplying the value of biomass with a conversion factor of 0.47 . So estimating carbon stocks using formulations, $\mathrm{C}=0.47 \mathrm{x}$ $\mathrm{B}$, where: $\mathrm{C}=$ carbon stock $(\mathrm{g})$; $\mathrm{B}=$ biomass value $(g)$.

\section{Estimation of $\mathrm{CO}_{2}$ uptake}

Estimation of $\mathrm{CO}_{2}$ uptake is calculated using carbon stock data that has been found through the formulation, $\mathrm{EC}=\mathrm{Cx} 3.67$; where $\mathrm{EC}=\mathrm{CO}_{2}$ uptake $\left(\mathrm{gCO}_{2}\right) ; \mathrm{C}=$ carbon stock $(\mathrm{g}) ; 3.67=\mathrm{a}$ constant for converting carbon to $\mathrm{CO}_{2} \cdot{ }^{10}$ Value of 3.67 derived from $44 / 12$, of which 44 , the molecular weight of $\mathrm{CO}_{2}$ compounds; 12 , molecular weight of atomic $\mathrm{C}$.

\section{Analysis of leaf litter decomposition rate}

Decomposition of teak leaf litter is done by incubating litter in a litter bag with a depth of $10 \mathrm{~cm}$ for 60 days incubation in 5 sample plots in city forest floor. Decomposition of litter follows the method, ${ }^{5}$ which is an example of dried litter of teak leaves, roasted at $80^{\circ} \mathrm{C}$ for 48 hours. Litter decomposition is done as follows: i) inserting leaf litter as much as $100 \mathrm{~g}$ into the litter bag, ii) the litter bag is buried with a depth of $10 \mathrm{~cm}$ at 5 places randomly in each sample plot, iii) the litter bag is taken every 15 days of incubation. Then litter in a litter bag is rinsed with fresh water and dried in an oven at $80^{\circ} \mathrm{C}$ for 48 hours, then weighed. After weighing, the litter is put again in a litter bag, then immersed in the original dirt floor. The decomposition rate of organic matter is expressed as the ratio of the dry litter weight remaining. The decomposition rate is calculated using the formula, $\mathrm{X}=(\mathrm{A}$ $\mathrm{B}) / \mathrm{A}$; where: $\mathrm{X}=$ decomposition rate; $\mathrm{A}=$ initial dry weight; $\mathrm{B}=$ final dry weight.

\section{Results and Discussion}

Biomass is the amount of organic matter stored in trees. The distribution of biomass in each tree component shows how much photosynthesis the tree has stored by plants. Estimation of biomass is very important for assessing carbon stocks and the effects of deforestation and carbon storage in the global carbon balance. ${ }^{11}$ The results of teak plantations observation in city forest on the Makassar campus, Hasanuddin University shows spacing of $3 \mathrm{~m}$ between trees; the same planting year and the height of the initial plant were almost the same (Figure 1).

The results of stem diameter and height measurement in 5 sample plots obtained an average diameter of $20.6 \mathrm{~cm}$ and an average height of $9.02 \mathrm{~m}$ (Table 1). The diamater data is used to determine the amount of biomass contained in each teak tree. Stem diameter is a factor that affects the amount of biomass contained and the amount of carbon stored in trees. Based on the stem diameter data obtained biomass, carbon stock and $\mathrm{CO}_{2}$ uptake data for each teak plant in Table 1.

The study only estimating above ground biomass. Results of this study indicate the total biomass, carbon stock and $\mathrm{CO}_{2}$ uptake in 5 sample plots were significantly different. Teak plantations in sample plot I produced biomass of $12,500.44 \mathrm{~g}$ with amount of 49 trees, an average diameter of $22 \mathrm{~cm}$ and an average height of $9.2 \mathrm{~m}$. Teak plantations biomass in sample plots I was highest compared to sample plots II, III, IV and V
(Table 1). At this research location the amount of biomass produced could still be increased considering that teak plants were still producing. Teak is a long lived annual plant, so the longer the biomass formation process also increases. Biomass is related to the photosynthesis process, where the biomass content increases because it absorbs $\mathrm{CO}_{2}$ from the air and converts it into organic compounds through photosynthesis. $\mathrm{CO}_{2}$ absorption is a teak plant service for the human environment to reduce $\mathrm{CO}_{2}$ emissions which is one of the causes of global warming. Forests have the potential to reduce $\mathrm{CO}_{2}$ in the atmosphere through storage in biomass as carbon stocks. The ability of tree stands to absorb and store carbon can be known from tree stand biomass ${ }^{12} \mathrm{CO}_{2}$ emissions can be reduced through several activities including managing forests sustainably, conserving carbon stocks and increasing forest carbon stocks.

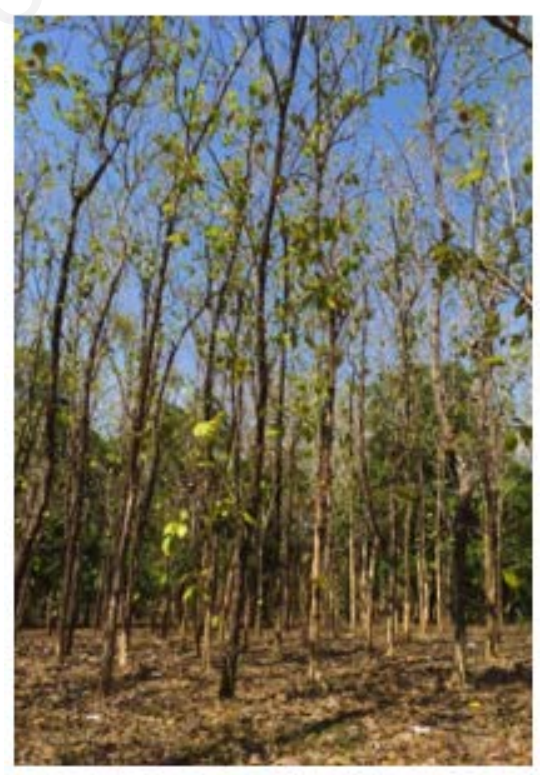

Figure 1. Teak Plantations in Makassar Campus of Hasanuddin University.

Table 1. Stem diameter, plant height, biomass, carbon stocks and $\mathrm{CO}_{2}$ uptake in 5 sample plots per unit area of 0.2 ha.

\begin{tabular}{lcccccc} 
Sample plots & $\begin{array}{c}\text { Number of } \\
\text { trees }\end{array}$ & $\begin{array}{c}\text { Stem diameter } \\
\text { average, } \mathrm{cm}\end{array}$ & $\begin{array}{c}\text { Plant height average, } \\
\mathrm{cm}\end{array}$ & $\begin{array}{c}\text { Biomass, } \\
\mathrm{g}\end{array}$ & $\begin{array}{c}\text { Carbon stocks, } \\
\mathrm{g}\end{array}$ & $\begin{array}{c}\text { Co } \mathbf{2}_{2} \\
\text { uptake, } \\
\mathrm{gCO}_{2}\end{array}$ \\
\hline I & 49 & 22 & 9.2 & $12,500.44^{\mathrm{a}}$ & $5,875.21^{\mathrm{a}}$ & $21,562.02^{\mathrm{a}}$ \\
II & 47 & 21 & 8.9 & $10,614.37^{\mathrm{b}}$ & $4,988.75^{\mathrm{b}}$ & $18,308.71^{\mathrm{b}}$ \\
\hline III & 46 & 19 & 8.9 & $7,992.34^{\mathrm{c}}$ & $3,756.40^{\mathrm{c}}$ & $13.785 .99^{\mathrm{c}}$ \\
IV & 48 & 20 & 9.0 & $9,539.41 \mathrm{~d}$ & $4,483.52^{\mathrm{d}}$ & $16.454 .52^{\mathrm{d}}$ \\
\hline V & 49 & 21 & 9.1 & $11,066.05^{\mathrm{e}}$ & $5,201.04^{\mathrm{e}}$ & $19,087.82^{\mathrm{e}}$ \\
Total & 239 & 103 & 45.1 & $51,712.61$ & $24,304.92$ & $89,199.06$ \\
\hline Average & 47.8 & 20.6 & 9.02 & $10,342.52$ & $4,860.98$ & $17,839.81$ \\
\hline
\end{tabular}

Numbers followed by the same letter are not significantly different at level of $95 \%$. 
Total biomass in 5 sample plots was $51,712.61 \mathrm{~g}$ with an area of 0.2 ha. To find out the total biomass in an area of 1 ha must be multiplied by five so that it produces biomass of $258,563.05 \mathrm{~g} / \mathrm{ha}^{13}$ Teak plantations with an average stem diameter of $16.6 \mathrm{~cm}$ and an average number of 42 tree in 5 sample plots with an area of 0.2 ha producing biomass was 26,161.13g and for biomass an area of 1 ha was $130,805.65 \mathrm{~g} / \mathrm{ha}^{14}$ The difference in the total biomass of a tree is influenced by the density of vegetation, the diversity of the diameter and the distribution of the specific gravity of the vegetation. Land use consisting of trees with species that have a high value of wood density, the biomass will be greater when compared to land that has species with low wood density values. Types of plantations with a high density of tree species will have a potential savings which tend to be greater than those of high density plantations but low species density.

Carbon stocks in 5 sample plots was 24,304.92g for 239 teak plants. While the total biomass for 5 sample plots is 51,712.61g. ${ }^{15}$ The percentage of carbon stocks in organic matter is $47 \%$ of the total biomass. ${ }^{7}$ The increase in the amount of carbon in line with the increase in biomass, the higher the amount of biomass the higher the amount of carbon stock. ${ }^{13}$ The amount of carbon stored in a land use is influenced by the amount of vegetation density, the denser the vegetation on the land, the more carbon is stored. ${ }^{16}$ When plants are cut down, there has been a decomposition of carbon that had been stored in plant biomass and then decomposed into the air. Most of the $\mathrm{C}$ elements that break down into the air are usually bound to $\mathrm{O}_{2}$ and become $\mathrm{CO}_{2}$. This change in carbon form then becomes the basis

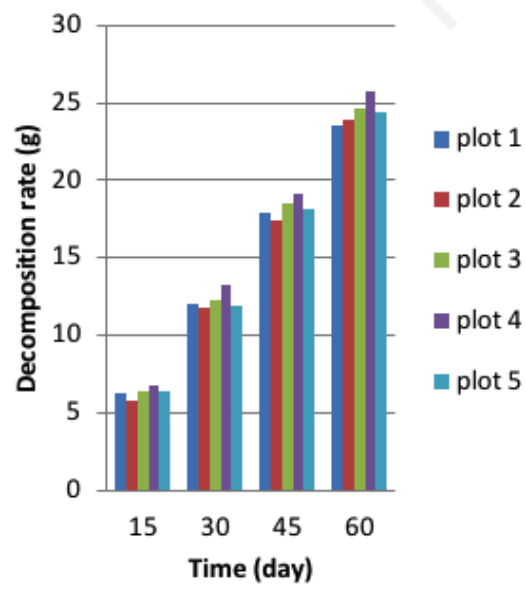

Figure 2. Decomposition rate of teak leaf litter. for calculating emissions. When vacant land is planted with plants, there will be a process of binding of element $\mathrm{C}$ from the air back into plant biomass. Therefore, the size of the plant volume can be a measure of the amount of carbon stored as biomass (carbon stock).

Teak plantations in 5 sample plots with an area of 0.2 ha were able to absorb $89,199.06 \mathrm{gCO}_{2}$ (Table 1). This means that teak plantations have the potential to reduce $\mathrm{CO}_{2}$ content in the atmosphere quite large. If the area of $1 \mathrm{ha}$, the $\mathrm{CO}_{2}$ absorbed reaches $445,995.30 \mathrm{gCO}_{2} /$ ha. Based on leaf organs, the teak leaf area index is greater than the leaf area of other trees. This is what might make teak trees have higher productivity than other trees. Leaf area affects the speed of photosynthesis with the wider form of teak stand leaves, the faster the photosynthesis process. ${ }^{7}$ Through the process of photosynthesis, $\mathrm{CO}_{2}$ in the air is absorbed by plants and with the help of sunlight and then converted into carbohydrates to be distributed throughout the plant's body and piled up in the form of leaves, stems, branches, fruits, and flowers. Although photosynthetic activity occurs in the leaves, the largest distribution of photosynthesis is used for stem growth. Stems generally have a better constituent of wood compared to other parts of the tree.

The results of leaf litter decomposition analysis with an initial dry weight of $100 \mathrm{~g}$ showed an average decomposition rate in 5 sample plots of $24.4 \mathrm{~g}$ for 60 days incubation. The highest average decomposition rate was $25.7 \mathrm{~g}$ in sample plot IV and the lowest was $23.5 \mathrm{~g}$ in sample plot I for 60 days incubation (Figure 2). Means that if the production of teak leaf litter in large quantities, high nutrient availability per unit area. ${ }^{17}$ The number of litter fall for 3 years with a spacing of $4 \times 4 \mathrm{~m}$ on 3 sites, namely $\mathrm{Na}$ Pralan of $10.114 \mathrm{~kg} / \mathrm{ha}$ (age of 47 years); Klangdong of $6,752 \mathrm{~kg} / \mathrm{ha}$ (age of 44 years) and Douglan of $4,399 \mathrm{~kg} / \mathrm{ha}$ (age of 32 years), in Thailand. ${ }^{18}$ Teak plant aged of 21 years, spacing of $4 \times 4 \mathrm{~m}$ has litter biomass of $7,400 \mathrm{~kg} / \mathrm{ha}$, in Jember, Indonesia. ${ }^{19}$ Teak plants aged of 23 years, spacing of $3 \times 3 \mathrm{~m}$ has litter biomass of 2.81 tons/ha, in Wanagama I, Yogyakarta, Indonesia.

This study produced the highest decomposition rate per day of 0.43 and the lowest of 0.39 . The results of this study are consistent with the research ${ }^{20}$ the highest decomposition rate of teak leaf litter was 0.65 per day with the addition of effective microbes and the lowest 0.42 per day, without the addition of microbes. ${ }^{21}$ Decomposition is the process of decomposing complex organic matter into simple organic materials involving microorganisms. ${ }^{22}$ The final result of decomposition of teak Tectona grandis Linn leaf litter, in the form of C, N, P, K and other micro elements that accumulate into the soil. ${ }^{23}$ Litter of teak leaves containing C of $50.92 \%, \mathrm{~N}$ of $1.28 \%$, P of $0.09 \%$, K of $0.52 \%$, $\mathrm{Ca}$ of $2.69 \%$ and $\mathrm{Mg}$ of $0.23 \%$. ${ }^{21}$ Teak leaf litter contained $\mathrm{N}$ of $2.68 \%$, P of $0.21 \% .{ }^{24}$ Litter of teak leaves containing $\mathrm{K}$ of $1.24 \%, \mathrm{Ca}$ of $2.93-4.81 \%$ and $\mathrm{Mg}$ of $0.55-0.70 \%$.

\section{Conclusions}

The teak Tectona grandis Linn plantations in city forest of Hasanuddin University have a total biomass of $51,712.61 \mathrm{~g}$ and a carbon stock of 24,304.92g. The total biomass and carbon stock is able to reduce $\mathrm{CO}_{2}$ in the atmosphere by as much as $89,199.06 \mathrm{~g} \mathrm{CO}_{2}$ per unit area of $0.2 \mathrm{ha}$. Teak leaf litter decomposed highest $25.7 \mathrm{~g}$ and lowest $23.5 \mathrm{~g}$ during 60 days incubation on forest floor.

\section{References}

1. Simon H. Management of forests with people: Theory and application of Teak forest in Java. Yogyakarta: Bigraf Publishing; 1999.

2. Putri AHM, Wulandari C. Potential carbon absorption in Shorea javanica at Pekon Gunung Kemala Krui, West Lampung. Sylva Lestari, 2015;3:13-20.

3. Krisnawati H, Rinaldi I, Wahyu CA, Silver H. Standard methods for estimating greenhouse gas emissions from the forestry sector in Indonesia. Bogor: Research center for forestry; 2015

4. Prescott CE, Blevins LL, Staley C. Litter decomposition in british columbia forests: controlling factors and influences of forestry activities. J Ecosystems Manag 2002;5:44-57.

5. Mahmudi, M. Production of litter waste and its decomposition rate in the Rhizopora forest, nguling, Pasuruan. Proceedings: ecological movement to awaken ecological intelligence and wisdom, on 2011, May 28. Brawijaya University, Malang; 2011

6. Fika AP, Siti S. Estimating the rate of litter biomass decomposition and production at several locations in Purwodadi botanical gardens. Plant Conservation Center Botanical Gardens Purwodadi Pasuruan 2010.

7. Fachrul MF. Bioecological sampling methods. Jakarta: Earth Literacy Publisher; 2006. 
8. Hairiah K, Rahayu S. Measurement of carbon stored in a variety of land use. World Agroforestry Center - ICRAF, SEA Regional Office, Brawijaya University, Malang; 2007.

9. Hairiah K, Sitompul SM, Noordwijk MV, Palm C. Methods for sampling of carbon stocks above and below ground. Bogor: ICRAF; 2011.

10. Asturi WI. Estimation of peatlands carbon stocks based on land depth stratification in Jabiren village., Pulang Pisau Regency. Department of Biology, ITS. Surabaya; 2016.

11. Ketterings QM, Coe R, Noordwijk M, et al. Reducing uncertainty in the use of allometric biomass equations for predicting above ground trees in biomass in mixed secondary forests. Forest Ecol Manag 2001;146:199-209.

12. Djaenudin D, Suryandari EV, Suka AP. A strategy to reduce the risk of failure to implement emissions reductions from deforestation and forest degradation: a case study in Merang, South Sumatra Province. J Forestry Pol Analys 2015;12:173-88.

13. Maruapey, A., Irnawati. Study of carbon sequestration in the Tectona grandis Linn in the Sorong regency greening area. Median .2019;11(1): 26-38

14. Rahayu SB, Lusiana B, Noordwijk MV. Estimation of above carbon reserves in various land use systems in Nunukan Regency, East Kalimantan. Bogor: ICRAF; 2007.

15. Brown S. Estimation of biomass and biomass change of tropical forest. Rome: FAO Forestry Paper; 1997.

16. Donato DC, Kauffman JB, Murdiyarso D, Kurnianto S, Stidham M, Kanninen M. Mangroves among the most carbonrich forests in the tropics. Nature Geoscience 2011;4: 293-7.

17. Luangjame J, Boontawe B, Kliangpibool N. Determination of deposition and leaves in teak plantations in Thailand. Water, Air and Soil pollution. 2001;130:935-40.

18. Supriyo H, Panduwati AT. Effect of forest stand types on litter biomass and soil organic matter (Case study at BKPH Sempolan, KPH Jember, East Java). J Forest Manag 2009;1:18-24.

19. Suwardi, Organic composting technology as a pillar of organic agriculture. Department of Soil Science and Land Resources. IPB University, Bogor; 2004

20. Andryani, Fahruddin, A. Abdullah.
Effect of bioactivator type toward the rate of decomposition of leaf litter of Tectona grandis Linn in the Campus of Hasanuddin University. Bioma : Bio J of Makassar; 2018;3:31- 42

21. Maradhy E. Application of mixed manure and mangrove sediment as an activator in the process of domestic waste decomposition. Thesis. Postgraduate of Hasanuddin University, Makassar; 2009.

22. Kumar JLN, Sajish PR, Kumar FN, Bhoi RK. Wood and leaf litter decomposition and nutrient and nutrient release from Tectona grandis Linn. in a tropical dry deciduous forest of Rajastan, Western India. J. Forest Sci., 2010;26:17-23.

23. Supriyo H., Daryono P. 2014. Nutrient content in new teak leaves falls on different treads. J. of forestry science. 2014; 8 (2): 108-16

24. Husni MSA, Ghazali HM, Suhaimi WC, Adzmi Y. Which leaf position in the crown of Tectona grandis should be sampled for fertility (nutritional) evaluation? J Trop Forest Sciences 1996;9:35-43 